\title{
PRODUKSI METABOLIT SEKUNDER STEVIOSIDA PADA KULTUR KALUS STEVIA (Stevia rebaudiana Bert. M.) DENGAN PENAMBAHAN ZPT 2,4-D DAN PEG (Polyethylene Glykol) 6000 PADA MEDIA MS (Murashige \& Skoog)
}

\author{
Fittriya Nur Laila, Evika Sandi Savitri*)
}

Jurusan Biologi- Fakultas Sains \& Teknologi UIN Maulana Malik Ibrahim Malang
Email : evikasandi@ yahoo.com

\begin{abstract}
Stevia rebaudiana is a member of the Asteraceae family, produce steviol glycosides (steviosida, rebaudiosida A, B, C, D, E and dulcosida A) which can be used as food additives such as food flavoring or sweetener in nutritional supplements. This study aims to determine the concentration of 2,4-D combination and PEG 6000 were effective in increasing the production of secondary metabolites in callus of stevia (Stevia rebaudiana Bert. M) in vitro. PEG 6000 is a way to manipulate media in vitro to increase secondary metabolite.

This research used Completely Randomized Design (CRD) with 12 factorial combination with three replications. The first factor is the provision of plant growth regulator 2,4-D $(1 \mathrm{mg} / \mathrm{L}, 2 \mathrm{mg} / \mathrm{L}$, and $3 \mathrm{mg} / \mathrm{L})$ and the second factor is the provision of PEG 6000 ( $0 \mathrm{mg} / \mathrm{L}, 5 \mathrm{mg} / \mathrm{L}, 15 \mathrm{mg} / \mathrm{L}$, and $25 \mathrm{mg} / \mathrm{L})$. The emerging callus (day), percentage (\%) of explants callus ( $g$ ), weight of callus, callus morphology (texture and color of the callus), and secondary metabolites steviosida were measured. Data were analyzed by analysis of variance (ANOVA) two way and to find a significant difference test Duncan's Multiple Range Test (DMRT) at 5\% significance level. Steviosida secondary metabolites were measured using High Performance Liquid Cromatography (HPLC).

The results showed that the combination treatment of $1 \mathrm{mg} / \mathrm{L} 2,4-D$ and $25 \mathrm{mg} / \mathrm{L}$ PEG 6000 is a combination of the most efficient way to get the amount of secondary metabolites steviosida $4.792 \mathrm{mg} / \mathrm{g}$. Observations callus morphology (texture and color of the callus) showed that the compact callus textured and colored brown due to osmotic stress of PEG 6000 has a high content of secondary metabolites steviosida

Keyword : Stevia callus, steviosida, PEG 6000
\end{abstract}

\section{LATAR BELAKANG}

Tumbuhan merupakan salah satu mahluk hidup ciptaan Allah SWT yang banyak memberikan manfaat bagi mahluk hidup yang lainnya, baik manusia maupun hewan. Allah SWT menganugrahkan mahluknya dengan berbagai macam tanaman, salah satunya adalah tanaman stevia (Stevia rebaudiana) yang dapat dimanfaatkan sebagai tanaman obat maupun sebagai pemanis untuk makanan. Allah SWT berfirman dalam surat Asy-Syu'ara (26) ayat 7: Artinya:

"Dan Apakah mereka tidak memperhatikan bumi, berapakah banyaknya Kami tumbuhkan di bumi itu berbagai macam (tumbuh-tumbuhan) yang baik?" (QS. Asy-Syu' ara ayat 7).

Shihab (2002) memberikan tafsiran bahwa ayat ini mengundang manusia untuk mengarahkan pandangan hingga batas kemampuannya memandang sampai mencakup seantero bumi, dengan aneka tanah dan tumbuhannya dan aneka keajaiban yang terdapat pada tumbuh-tumbuhannya.

Allah SWT telah menumbuhkan berbagai macam tumbuh-tumbuhan, salah satunya tanaman stevia (Stevia rebaudiana Bertoni) yang ditumbuhkan oleh Allah dengan berbagai manfaat. Tanaman ini biasanya digunakan oleh masyarakat sebagai pengganti gula sintetis sebab pada daun stevia terdapat glikosida dengan tingkat kemanisan kurang lebih 200-300 kali lebih manis dibandingkan gula tebu atau sukrosa serta sifatnya yang nonkalori sehingga aman jika dikonsumsi oleh penderita diabetes atau orang yang sedang melakukan program diet.

Beberapa negara termasuk indonesia stevia sedang dikembangkan sebagai pemanis 
alami alternatif sebagai pengganti sakarin dan siklamat yang diduga beresiko bagi kesehatan, menurut hasil penelitian kedua pemanis sintetis tersebut dapat menyebabkan kanker sehingga penggunaanya mulai dikurangi. Menurut Cahyadi (2008) dijelaskan bahwa pemanis sintetis merupakan bahan tambahan yang dapat menyebabkan rasa manis pada pangan, tetapi tidak memiliki nilai gizi. Bahan sintetis ini memiliki sifat yang karsinogenik yaitu penyebab kanker. Beberapa pemanis sintetis yang telah dikenal dan banyak digunakan adalah sakarin, siklamat dan aspartam. Berdasarkan penjelasan tersebut keberadaan stevia sangat sesuai dengan harapan yang diinginkan oleh masyarakat, mengingat gula merupakan salah satu kebutuhan pokok masyarakat di Indonesia.

Stevia rebaudiana Bertoni (FamiliAsteraceae) adalah satu dari 154 jenis stevia dan satu dari dua spesies yang menghasilkan pemanis steviol glikosida (Madan, 2010., Jitendra, 2012). Glikosida dalam daun stevia terdiri dari steviosida, beberapa rebaudiosida termasuk rebau-diosida A (reb-A), dulkosida, dan beberapa senyawa lainnya (Geuns, 2003). Glikosida tidak mengandung kalori dan mempunyai indeks glikemat hampir nol sehingga sesuai untuk penderita diabetes dan seseorang yang sedang melakukan diet makanan untuk menurunkan berat badan. Stevia digunakan pada minuman ringan rendah-kalori, bahan makanan, pasta gigi, bahan kosmetika, antioksidan, antihipertensi, dan berbagai produk lain (Sumaryono dkk, 2011)

Sesuai dengan Chatsudthipong (2009) steviosida adalah glikosida diterpenoid, yang terdiri dari aglikon (steviol) dan tiga molekul glukosa. Fatima (2010) menambahkan senyawa pemanis diisolasi dari daun Stevia. Senyawa ini disebut sebagai "stevioside" yang terdiri dari tiga molekul komplek glukosa dan satu molekul aglikon steviol, alkohol karboksilat diterpenik.

Berdasarkan banyaknya manfaat dari tanaman stevia inilah yang mendasari untuk dilakukannya kultur jaringan yaitu kalus. Kultur kalus juga menjadi suatu alternatif untuk meningkatkan sintesa metabolit sekunder yang mempunyai nilai komersial tinggi. Teknik in vitro mempunyai keuntungan antara lain produksi metabolit sekunder dapat dilakukan sepanjang tahun dan tanpa dipengaruhi oleh cuaca, serta dapat dikembangkan untuk produksi biomassa metabolit secara besar-besaran, sehingga kultur merupakan cara yang dapat digunakan dalam meningkatkan sintesis metabolit sekunder. Kelebihan penggunaan kultur jaringan dalam produksi senyawa bioaktif dibanding dengan budidaya tanaman secara utuh antara lain adalah tidak adanya keterbatasan iklim, tidak memerlukan lahan yang luas, dan senyawa bioaktif dapat dihasilkan secara terus menerus dalam keadaan yang terkontrol (Habibah, 2009).

Produktivitas tumbuhan dalam menghasilkan metabolit sekunder dapat ditingkatkan dengan beberapa cara, yaitu mengoptimasi faktor fisiologi lingkungan hidup sel diantaranya memanipulasi nutrisi media tumbuh, zat pengatur tumbuh, prekusor dan elisitor untuk sintesis metabolit sekunder (Zhao, 2005 dalam Yulinda 2010). Pada penelitian ini menggunakan cara manipulasi nutrisi media tumbuh untuk meningkatkan kandungan metabolit sekunder.

Menurut Rahayu (2005) dalam Yulinda (2010) melaporkan PEG adalah senyawa yang dapat menurunkan potensial osmotik larutan melalui aktivitas matriks sub-unit etilena oksida yang mampu mengikat molekul air dengan ikatan hidrogen. Karena turunnya potensial osmotik larutan, air yang ada pada medium tidak dapat diserap oleh tanaman, sehingga tanaman mengalami stress osmosis.

Pemberian PEG akan menyebabkan kekurangan air sehingga akan menginduksi protein, mengkode gen-gen pembentuk enzim yang terlibat dalam biosintesis metabolisme sekunder. Dengan meningkatnya kandungan enzim dalam jaringan tanaman maka diharapkan kandungan metabolit sekunder dapat meningkat. Aktivitas enzim dipengaruhi antara lain oleh adanya prekusor, senyawa yang bersangkutan dan akumulasi produk metabolisme sekunder tersebit (Ernawati, 1992)

Hal ini sesuai dengan penelitian dari Hartanti (2013) pada tanaman tembakau (Nicotiana tabacum var. Prancak 95) melaporkan bahwa tekstur kalus yang dibentuk oleh eksplan pada medium (induksi kalus) yang ditambahkan polyethilene glicol (PEG) berbeda dengan tekstur kalus yang dibentuk oleh eksplan pada kontrol. Tekstur kalus pada perlakuan dengan polyethylene glicol (PEG) adalah remah. Sedangkan penambahan PEG 6000 pada media subkultur menyebabkan kalus bertekstur kompak. Hal ini sesuai dengan penelitian Zulhilmi (2012) pada Kalus Gatang (Spilanthes acmella Murr.) melaporkan bahwa semua kalus yang diperlakukan (ditambahkan PEG 6000 
pada media subkultur) berstruktur kompak dan berwarna putih kekuningan.

Konsentrasi PEG 6000 yang digunakan pada penelitian ini yaitu $0 \mathrm{mg} / \mathrm{L}, 5 \mathrm{mg} / \mathrm{L}, 15$ $\mathrm{mg} / \mathrm{L}$, dan $25 \mathrm{mg} / \mathrm{L}$. Penetapan konsentrasi tersebut berdasarkan pada penelitian Hartanti (2013) pada tanaman tembakau (Nicotiana tabacum var. Prancak 95), yaitu dengan konsentrasi $0 \mathrm{mg} / \mathrm{L}, 15 \mathrm{mg} / \mathrm{L}, 20 \mathrm{mg} / \mathrm{L}, 25$ $\mathrm{mg} / \mathrm{L}$, dan $30 \mathrm{mg} / \mathrm{L}$. Berdasarkan hasil penelitiannya dapat disimpulkan bahwa konsentrasi PEG yang ditoleransi eksplan untuk membentuk kalus adalah $25 \mathrm{mg} / \mathrm{L}$ dengan kalus yang terbentuk berwarna coklat dan tekstur remah. Pada penelitian Hartanti penambahan PEG ditambahkan secara langsung pada media induksi kalus (bukan subkultur). Sedangkan penggunaan konsentrasi dalam persentase (\%) tidak digunakan karena ditakutkan konsentrasi PEG terlalu besar sehingga dapat menyebabkan kalus tidak tumbuh dan mati. Penggunaan konsentrasi dalam bentuk persentase (\%) sering digunakan pada media subkultur.

Berdasarkan penelitian Zulhilmi (2012) pada Kalus Gatang (Spilanthes acmella Murr.) menunjukkan perlakuan PEG 2\% dan 5\% meningkatkan sintesis alkaloid sedangkan kandungan terpenoid meningkat pada perlakuan $3 \%$ dan $4 \%$ PEG. Adapun senyawa fenolik hanya muncul pada perlakuan PEG 4\%. Yulinda (2010) melaporkan bahwa kandungan metabolit sekunder triterpenoid pada tanaman Centella asiatica meningkat dengan penambahan 1 dan 2 $\%$ PEG. Sedangkan penelitian Fakhri (2010) pada tanaman Theobroma cacao menunjukkan kandungan metabolit sekunder katekin terbanyak dihasilkan pada penambahan PEG $1 \%$.

Berdasarkan uraian diatas, penelitian ini diharapkan dapat meningkatkan kandungan metabolit sekunder (steviosida) pada tanaman Stevia rebaudiana dengan menginduksi kalus pada media MS yang ditambahkan berbagai konsentrasi ZPT 2,4-D dan PEG 6000.

\section{METODOLOGI}

Penelitian ini merupakan penelitian eksperimental yang menggunakan Rancangan Acak Lengkap (RAL) faktorial yaitu pemberian zat pengatur tumbuh 2,4-D $(1 \mathrm{mg} / \mathrm{L}, 2 \mathrm{mg} / \mathrm{L}$, dan $3 \mathrm{mg} / \mathrm{L}$ ) pada media MS (Murashige \& Skoog) yang merupakan faktor pertama dan pemberian PEG $6000(0 \mathrm{mg} / \mathrm{L}, 5 \mathrm{mg} / \mathrm{L}, 15$ $\mathrm{mg} / \mathrm{L}$, dan $25 \mathrm{mg} / \mathrm{L}$ ) yang merupakan faktor kedua. Dengan demikian, dalam penelitian ini terdapat 4 X 3 kombinasi atau 12 kombinasi dengan 3 ulangan. Sehingga secara keseluruan terdapat 36 unit. Faktor pertama adalah konsentrasi 2,4-D yang terdiri dari 3 taraf: $\mathrm{K} 1=$ 2,4-D dengan konsentrasi $1 \mathrm{mg} / \mathrm{L}, \mathrm{K} 2=2,4-\mathrm{D}$ dengan konsentrasi $2 \mathrm{mg} / \mathrm{L}, \mathrm{K} 3=2,4-\mathrm{D}$ dengan konsentrasi $3 \mathrm{mg} / \mathrm{L}$. Faktor kedua adalah kosentrasi PEG 6000 yang terdiri dari 4 taraf: P1 = PEG 6000 dengan konsentrasi 0 mg/L, P2 = PEG 6000 dengan konsentrasi $5 \mathrm{mg} / \mathrm{L}, \mathrm{P} 3=$ PEG 6000 dengan konsentrasi $15 \mathrm{mg} / \mathrm{L}, \mathrm{P} 4=$ PEG 6000 dengan konsentrasi $25 \mathrm{mg} / \mathrm{L}$

Media MS ditimbang sebanyak 4,43 gr, serta gula ditimbang sebanyak 30 gr, kemudian ditambahkan ke dalam masing-masing beaker glass yang telah berisi aquades, PEG 6000 dan ZPT. Dihomogenkan dan diukur $\mathrm{pH}$ larutan media dengan $\mathrm{pH}$ meter, yaitu 5,8. Agar ditimbang sebanyak 7 gr dan ditambahkan dalam masing-masing beaker glass yang berisi aquades, PEG 6000, MS, gula, dan ZPT. Kemudian media dimasak pada hot plate dengan stirer hingga mendidih serta homogen. Media yang telah mendidih dituang ke dalam botol kultur $\pm 20 \mathrm{ml}$, kemudian ditutup dengan pastik dan diikat dengan karet serta di beri kertas label.

\section{Tahap Pengamatan}

Pengamatan dilakukan dengan 3 tahap: Pengamatan dilakukan setiap hari untuk melihat ada atau tidaknya perkembangan dan munculnya kalus pertama kali pada eksplan, serta ada tidaknya kontaminasi pada eksplan. Pengamatan kedua yaitu pengamatan interval 2 minggu sekali untuk mengetahui tekstur dan warna kalus. Pengamatan ketiga yaitu pengamatan akhir yang dilakukan setelah 4 minggu penanaman terdiri dari pengamatan prosentase eksplan membentuk kalus, berat kalus dan uji kadar steviosida pada kalus Stevia rebaudiana.

\section{Parameter pengamatan:}

Pengamatan munculnya kalus pertama kali dinyatakan dalam HST (Hari Setelah Tanam) yang ditandai dengan pembengkakan eksplan. Pengamatan warna kalus yang dilakukan setiap hari dengan diamati perubahan warna yang terjadi pada setiap kalusnya. Pengamatan kontaminasi dengan mengamati secara langsung yang terjadi pada media dan eksplan yang dapat diakibatkan oleh mikroorganisme. Tekstur kalus diamati secara visual pada penampakan kalus yaitu kalus remah, kalus kompak, dan kalus intermediet. 
Pengamatan prosentase kalus yang dilakukan dengan menghitung banyaknya eksplan yang membentuk kalus dibandingkan dengan total eksplan yang ditanam dilakukan di akhir pengamatan.

\% Eksplan berkalus = Eksplan berkalus tiap perlakuanTotal eksplan tiap perlakuan x $100 \%$.

Pengamatan berat kalus dilakukan secara destruktif pada minggu keempat menggunakan timbangan analitik untuk mengetahui berat akhir kalus kemudian.

Berat kalus/Ulangan $=$ Berat akhir - Berat eksplan awal tiap botol / Jumlah kalus yang tumbuh pada setiap botol

Rata-rata berat kalus $=$ Jumlah berat kalus seluruh ulangan/ Ulangan

Pengamatan kandungan metabolit sekunder (steviosida) dengan menggunakan metode HPLC atau KCKT.

\section{Tahap Uji Metabolit Sekunder}

Pengujian senyawa fitokimia hasil metabolit sekunder dilakukan dengan menggunakan metode Kromatografi Cair Kinerja Tinggi (KCKT) atau yang sering disebut dengan High Performance Liquid Cromatography (HPLC).

\section{Analisis Data}

Data pengamatan berupa data kualitatif dan kuantitatif. Data kualitatif berupa pengamatan secara visual meliputi morfologi kalus, dan hari muncul kalus, sedangkan data kuantitatif berupa persentase kalus berat kalus, dan kadar steviosida. Data dianalisis dengan menggunakan analisis variansi (ANAVA) faktorial untuk mengetahui adanya pengaruh pemberian ZPT 2,4-D dan PEG 6000 pada media MS terhadap kandungan steviosida pada kalus Stevia rebaudiana secara in vitro. Apabila terdapat perbedaan yang nyata maka dilanjut dengan DMRT pada taraf 5\%.

\section{HASIL}

Penelitian Janarthanam (2010) tentang kultur kalus untuk biosintesis steviosida menggunakan eksplan daun stevia yang menggunakan medium MS dengan penambahan 2,4-D, NAA yang dikombinasikan dengan BA menghasilkan kalus berwarna hijau kekuningan dengan struktur kalus kompak dan keras.
Sedangkan pada penelitian ini warna kalus yang dominan adalah coklat, warna coklat ini diperoleh karena adanya penambahan zat kimia berupa PEG 6000 sebagai osmotikum pada media induksi kalus. Berdasarkan analisis HPLC untuk uji kadar steviosida yang tertinggi didapatkan pada kalus berwarna coklat.

Perubahan warna kalus menjadi kecoklatan atau coklat menunjukkan terjadinya senyawa fenolik. Menurut Naz (2008) fenol yang teroksidasi akan membentuk kuinon dan kuinon adalah senyawa yang menyebabkan warna coklat pada kultur kalus. Intensitas warna coklat berkorelasi positif dengan hiperaktivitas enzim oksidatif. Peningkatan enzim tersebut terkait dengan reaksi pertahanan jaringan dari stres oksidatif. Menurut Matheka et al., (2008) dalam Zulhimi (2012) pada kalus gantang untuk meningkatkan kandungan metabolit sekunder dengan PEG, menyatakan bahwa pencoklatan eksplan merupakan efek dari hilangnya air akibat sel mangalami cekaman osmotik.

Menurut Ariningsih (2003) perubahan warna pada kalus juga tergantung pada media perkembangannya. Cekaman yang diberikan oleh media pada kalus mengindikasi kalus akan berubah warna lebih tua dari kalus segar. Dengan demikian semakin tua perubahan warna kalus pada suatu media menunjukkan adanya aktifitas biosintesis metabolit sekunder lebih tinggi dan lebih besar.

\section{Menurut Hendaryono}

menyatakan bahwa warna kalus yang bervariasi disebabkan oleh adanya pigmentasi, pengaruh cahaya dan bagian tanaman yang dijadikan sebagai sumber eksplan. Hal ini sesuai dengan hasil penelitian ini, dimana awal terbentuknya kalus berwarna hijau atau hijau kekuningan yang lama kelamaan berubah menjadi kuning kecoklatan atau coklat yang disebabkan oleh cekamanosmosis dari PEG 6000 dalam media tumbuh. Berdasarkan penelitian Zulhilmi (2012) pada kalus gantang didapatkan hasil dari segi warna, kalus yang diberi perlakuan PEG 0-3\% berwarna kuning kecoklatan pada bagian bawah dan putih pada bagian atas. Bagian putih menunjukkan sel-sel yang baru terbentuk. Sedangkan kalus yang diberi perlakuan PEG 4$5 \%$ berwarna coklat.

\section{Pengaruh Konsentrasi 2,4-D dan PEG 6000 terhadap Kadar Steviosida Kalus Stevia (Stevia rebaudiana Bert.)}

Metabolit sekunder adalah salah satu tujuan dalam teknik kultur jaringan tanaman, 
dimana diharapkan dapat meningkatkan kandungan metabolit sekunder lebih tinggi dari pada yang diperoleh secara langsung dari alam. Dalam hal ini terdapat suatu cara yang dinamakan elisitasi untuk meningkatkan kandungan metabolit sekunder. Dimana menurut Mattel dan Smith (1993) dalam Pandiangan (2011), agar produksi metabolit sekunder tinggi maka perlu optimasi faktor-faktor internal dan eksternal. Optimasi faktor tersebut dapat dilakukan dalam dua tahap yaitu tahap pertumbuhan dan tahap produksi. Pada tahap pertumbuhan, kondisi kultur diarahkan untuk memproduksi biomassa sel dalam waktu dekat, sedangkan tahap produksi dilakukan pemindahan biomassa sel ke dalam medium produksi dengan tujuan pengkondisian kultur untuk produksi metabolit sekunder.

Berdasarkan keterangan tersebut, penelitian ini untuk meningkatkan kandungan metabolit sekunder menggunakan metode cekaman abiotik (osmotikum) yang mengakibatkan kalus mengalami stres abiotik dengan PEG 6000 yang ditambahkan pada media MS induksi kalus stevia. Dalam hal ini, untuk mengetahui pengaruh konsentrasi 2,4-D dan PEG 6000 terhadap kandungan metabolit sekunder steviosida kalus stevia (Stevia rebaudiana Bert.) dilakukan dengan menggunakan metode HPLC (High Performance Liquid Chromatography). Adapun hasil analisa Kandungan Metabolit Sekunder pada Kalus stevia (Stevia rebaudiana Bert.) dengan penambahan 2,4-D dan PEG 6000 dapat dilihat pada tabel dibawah ini.

Tabel 1. Kadar Steviosida pada kalus (Stevia rebaudiana Bert.) setelah Pengamatan Selama 4 Minggu setelah tanam

\begin{tabular}{|c|c|c|c|}
\hline No & Perlakuan & $\begin{array}{c}\text { Kadar steviosida pada kalus } \\
\text { (Stevia rebaudiana Bert.) }\end{array}$ & Berat Sample \\
\hline 1 & Daun|Stevia & $4,113 \mathrm{mg} / \mathrm{g}$ & $0,5 \mathrm{~g}$ \\
\hline 2 & K1P1 & $4,297 \mathrm{mg} / \mathrm{g}$ & $0,2 \mathrm{~g}$ \\
\hline 3 & K1P2 & $4,536 \mathrm{mg} / \mathrm{g}$ & $0,2 \mathrm{~g}$ \\
\hline 4 & K1P3 & $4,693 \mathrm{mg} / \mathrm{g}$ & $0,2 \mathrm{~g}$ \\
\hline 5 & K1P4 & $4,792 \mathrm{mg} / \mathrm{g}$ & $0,2 \mathrm{~g}$ \\
\hline 6 & K2P1 & $4,264 \mathrm{mg} / \mathrm{g}$ & $0,2 \mathrm{~g}$ \\
\hline 7 & K2P2 & $4,675 \mathrm{mg} / \mathrm{g}$ & $0,2 \mathrm{~g}$ \\
\hline 8 & K2P3 & $4,697 \mathrm{mg} / \mathrm{g}$ & $0,2 \mathrm{~g}$ \\
\hline 9 & K2P4 & $4,835 \mathrm{mg} / \mathrm{g}$ & $0,2 \mathrm{~g}$ \\
\hline 10 & K3P1 & $4,354 \mathrm{mg} / \mathrm{g}$ & $0,2 \mathrm{~g}$ \\
\hline 11 & K3P2 & $4,583 \mathrm{mg} / \mathrm{g}$ & $0,2 \mathrm{~g}$ \\
\hline 12 & K3P3 & $4,846 \mathrm{mg} / \mathrm{g}$ & $0,2 \mathrm{~g}$ \\
\hline 13 & K3P4 & $4,768 \mathrm{mg} / \mathrm{g}$ & $0,2 \mathrm{~g}$ \\
\hline
\end{tabular}

Data yang diperoleh pada tabel diatas memperlihatkan bahwa pemberian ZPT 2,4-D dan PEG 6000 ke dalam media tumbuh kalus dapat meningkatkan konsentrasi metabolit sekunder secara umum. Hal ini menunjukkan bahwa pemberian PEG 6000 menyebabkan kalus mengalami stress sehingga memacu pembentukan metabolit sekunder. Menurut Rahayu (2005) dalam Zulhilmi (2012) kehadiran PEG pada medium dapat menurunkan potensial osmotik larutan sehingga ketersediaan air bagi tanaman akan berkurang. Berkurangnya ketersediaan air bagi tanaman ini mengganggu berbagai proses metabolisme.

Berdasarkan hasil penelitian terbukti bahwa dengan metode teknik kultur jaringan mampu meningkatkan kandungan metabolit sekunder steviosida pada kalus stevia, dimana berdasarkan hasil uji HPLC (Tabel 4.5) kandungan steviosida pada daun stevia $(0,5 \mathrm{~g})$ didapatkan hasil 4,113 $\mathrm{mg} / \mathrm{g}$, sedangkan kandungan steviosida kalus $(0,2 \mathrm{~g})$ pada media yang perlakuan kultur kalus didapatkan kisaran 4,297 mg/g hingga $4,846 \mathrm{mg} / \mathrm{g}$.

Menurut penelitian Shirwaikar (2011) dari hasil uji HPLC dengan menggunakan sampel bubuk stevia $(5 \mathrm{mg} / \mathrm{ml})$ dan ekstrak daun stevia $(5 \mathrm{mg} / \mathrm{ml})$ ditemukan kandungan steviosida ditemukan 8,859 \% dan 3,703\%. Sedangkan menurut Madan (2010) menyatakan bahwa dalam daun stevia terkandung steviosida (6-18 \% bobot segar dalam daun) yang merupakan glikosida manis dan telah diuji tingkat kemanisannya 300 kali lebih manis dari sukrosa. Dibawah ini merupakan grafik kadar steviosida:

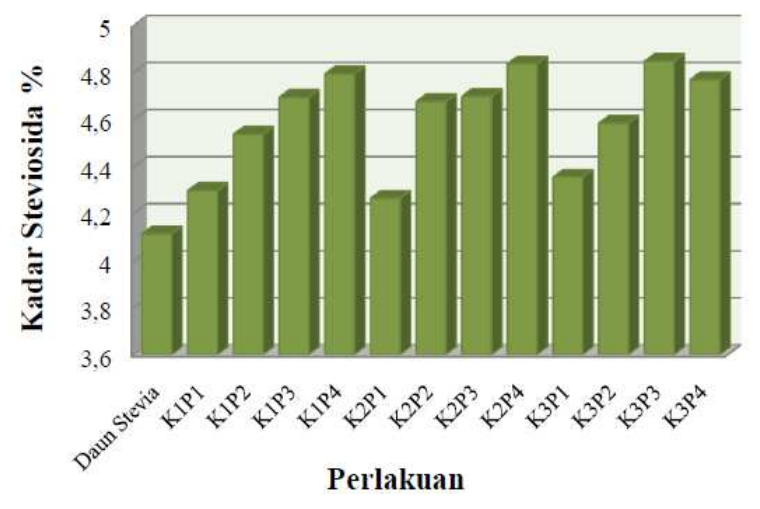

Gambar 1. Grafik kadar steviosida pada kalus Stevia rebaudiana

Berdasarkan grafik kadar steviosida pada kalus Stevia rebaudiana Bert. (Gambar 1) dapat diketahui bahwa kandungan metabolit sekunder steviosida pada kalus stevia (Stevia rebaudiana Bert.) yang lebih tinggi dihasilkan oleh perlakuan K3P3 (3 mg/L 2,4-D + $15 \mathrm{mg} / \mathrm{L}$ PEG 6000) yaitu sebesar 4,846 mg/g, dan K2P4 
(2 mg/L 2,4-D + 25 mg/L PEG 6000) yaitu sebesar $4,835 \mathrm{mg} / \mathrm{g}$, tetapi jika dilihat dari perlakuan K1P4 (1 mg/L 2,4-D + 25 mg/L PEG 6000) didapatkan hasil yang tidak berbeda jauh yaitu 4,792 mg/g, sehingga penggunaan konsentrasi 2,4-D dan PEG 6000 yang lebih efisien didapatkan pada perlakuan K1P4 (1 $\mathrm{mg} / \mathrm{L}$ 2,4-D + $25 \mathrm{mg} / \mathrm{L}$ PEG 6000), hal ini didasarkan pada penggunaan dari 2,4-D mengingat harga 2,4-D lebih mahal dari pada PEG 6000. Sedangkan kandungan metabolit sekunder steviosida yang terendah didapatkan

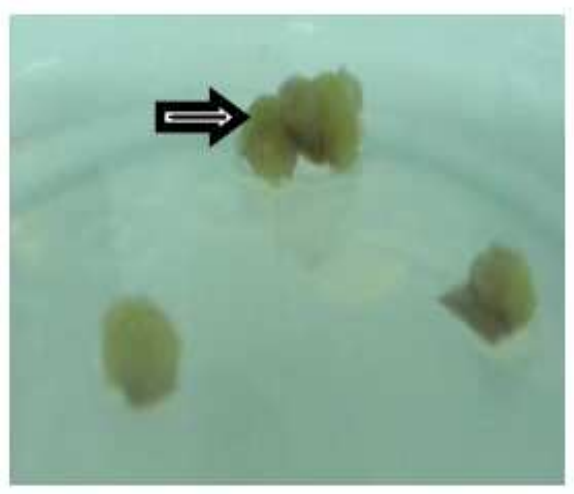

A. dariperlakuan K2P1 (2 mg/L 2,4-D + 0 mg/L PEG 6000) yaitu sebesar 4,264 mg/g. Maka berdasarkan Gambar 1 dapat diamati bahwa kandungan steviosida meningkat seiring dengan peningkatan 2,4-D yang dikombinasikan dengan PEG 6000 dan menunjukkan kandungan steviosida yang lebih rendah seiring dengan rendahnya konsentrasi 2,4-D tanpa PEG 6000. Kualitas kalus ditunjukkan pada Gambar 2, kalus berwarna hijau sebelum perlakuan dan berubah berwarna coklat setelah perlakuan, dan menunjukkan tekstur kompak.

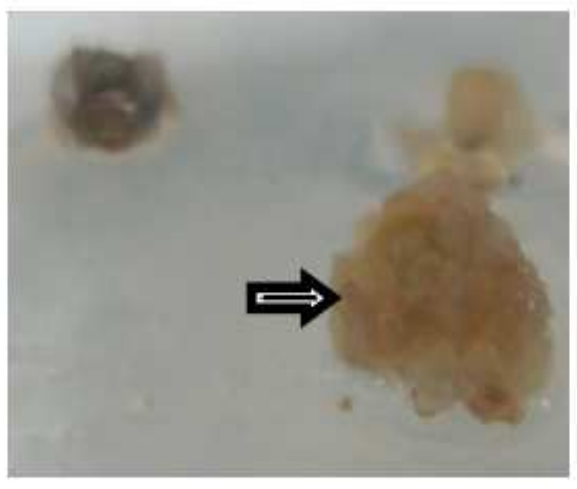

B.

Gambar 2. Tekstur dan warna kalus sebelum perlakuan (A), setelah perlakuan (B)

\section{PEMBAHASAN}

PEG merupakan kimia organik yang digunakan sebagai osmotikum dan menyebabkan stres air pada tanaman. Senyawa kimia tersebut mempunyai sifat tidak aktif, tidak bermuatan ion, kelarutan dalam air tinggi walaupun mempunyai cincin rantai tinggi lebih dari 4000 dapat menginduksi stres air pada tanaman dengan menurunkan potensial larutan nutrien, polietilen glikol tidak terserap dan tidak mengakibatkan keracunan pada tanaman (Dami dan Hughes, 1997).

Penggunaan PEG 6000 dalam jangka panjang pada tanaman relatif aman, karena PEG 6000 tidak dapat masuk ke dalam jaringan tanaman atau dinding selulosa. Senyawa PEG dengan berat molekul 6000 dipilih karena mampu bekerja lebih baik pada tanaman daripada PEG dengan berat molekul yang lebih rendah dan yang lebih tinggi. PEG di bawah 6000 diduga kurang efektif karena kemampuan dalam mengikat air terlalu kecil. Besarnya kemampuan larutan PEG dalam mengikat air bergantung pada berat molekul dan konsentrasinya, akan tetapi PEG dengan berat molekul lebih tinggi dari 6000 akan mengikat air yang terlalu besar sehingga tanaman semakin sulit menyerap air mengakibatkan stresosmosis yang berlebihan dan tanaman bisa mati. Hal ini sesuai dengan yang ditulis oleh Sulastri (2010) pada penelitiannya tentang tanaman alfalfa, yaitu alasan digunakan PEG 6000 MW karena sifatnya sebagai polimer yang non ionik dapat berikatan dengan molekul air melalui dua ikatan: ikatan hidrogen dan ikatan van der waals (menurunkan nilai potensial air). Sehingga diharapkan dengan terikatnya molekul air dalam media oleh PEG 6000 ketersediaan air untuk diserap kalus stevia semakin sedikit. PEG juga bersifat tidak toksik dan dengan berat molekul yang besar, yaitu $6000 \mathrm{~g} / \mathrm{mol}$, maka PEG 6000 tidak akan mudah melakukan penetrasi kedalam jaringan tanaman.

Secara garis besar diduga bahwa PEG 6000 akan mengaktifkan signal yang berfungsi menginduksi gen-gen yang berperan dalam produksi senyawa steviosida yang terjadi melalui jalur biosintesis yaitu jalur asam mevalonat. Menurut Sulastri (2010) dalam penelitiannya pada kalus alfalfa menuliskan bahwa tanaman memiliki respon yang berbeda untuk beradaptasi pada kondisi stress osmotik. Mekanisme ini salah satunya dikendalikan oleh osmoregulator. Hal ini mungkin terjadi pada 
kalus yang ditumbuhkan pada media dengan penambahan PEG. Pada beberapa tanaman ditemukan glycine betain dan prolin sebagai osmoprotektan. Beberapa penelitian menunjukkan behwa molekul-molekul terakumulasi dalam sel tanaman selama mengalami kondisi stres osmotik akan mencegah kerusakan sel karena dehidrasiseluler dengan menjaga keseimbangan tekanan osmotik dalam sitoplasma dan lingkungan.

Pemberian PEG akan mempengaruhi penyerapan air sehingga kalus mengalami stres. Kekurangan air menurunkan tekanan turgor pada dinding sel. Kehilangan tekanan turgor pada sel yang dikulturkan di medium perlakuan diindikasikan pula sebagai signal bagi membran plasma untuk mengaktifkan protein tertentu yang mendorong sintesis ABA (Asam absisat). Keberadaan ABA pada akhirnya akan merangsang terbentuknya protein yang berperan sebagai mekanisme toleransi terhadap cekaman kekeringan (protein osmoprotektan) (Hartanti, 2013). Protein osmoprotektan dapat berinteraksi dengan reseptor sistem membran plasma (Konstantinova, 2002 dalam Hardiawan, 2013) menyebabkan peningkatan $\mathrm{Ca} 2+$ interseluler yang bertindak sebagai second messenger untuk menginduksi transkripsi dan translasi enzimenzim yang terlibat dalam jalur metabolit sekunder (Dmitrev, 1996 dan Silalahi, 1999).

Penambahan zat kimia (PEG 6000) sebagai osmotikum mampu meningkatkan aktivitas enzim yang berperan dalam biosintesis (Mathius, 2006). Pemberian PEG akan menyebabkan kekurangan air sehingga akan menginduksi protein, mengkode gen-gen pembentuk enzim yang terlibat dalam biosintesis metabolisme sekunder. Dengan meningkatnya kandungan enzim dalam jaringan tanaman maka diharapkan kandungan metabolit sekunder dapat meningkat pula. Diduga enzim yang dapat memacu pembentukan senyawa terpenoid antara lain adalah enzim asetil CoA asetiltransferase, HMG-CoA reeduktase, enzim mevalonat kinase dan enzim fosfomevalonat kinase. Enzim lain yang berperan dalam memacu pembentukan senyawa terpenoid khususnya steviosida adalah CPP synthase, kaurene sintase, ent kaurene oxidase, entKaurenoic Acid 13-Hydroxylase.

Menurut Larcher dalam Salisbury dan Ross (1995), tumbuhan yang mulai mendapatkan faktor cekaman mengalami reaksi tanda bahaya yang ditandai dengan mulai terganggunya fungsi fisiologis dari biasanya.
Kemudian berlangsung tahap resistensi yaitu organisme beradaptasi pada faktor cekaman. Tahap selanjutnya akan terjadi kematian jika faktor cekaman meningkat atau terus berlangsung.

Meningkatnya kandungan steviosida selain dipengaruhi oleh PEG 6000, juga dipengaruhi oleh ZPT dalam hal ini adalah 2,4D. Menurut Salisbury dan Ross (1995) dijelaskan bahwa zat pengatur tumbuh $(2,4-\mathrm{D})$ terikat pada membran protein penerima di membran plasma sel. Kompleks ikatan ini mengaktifkan enzim fosfolipase C (PLC). Enzim PLC ini menghidrilisis fosfatidil inositol 4,5-bifosfat (P1P2) menghasilkan inositol 1,4,5trifosfat (IP3) dan diasil gliserol (DAG). IP3 bergerak menuju vakuola sehingga menyebabkan terlepasnya $\mathrm{Ca} 2+$ simpanan masuk ke dalam sitosol. Meningkatnya konsentrasi $\mathrm{Ca} 2+$ di sitosol menyebabkan empat buah $\mathrm{Ca} 2+$ bergabung membentuk kompleks dengan kalmodulin tidak aktif menjadi kalmodulin aktif, hal ini mengaktifkan beberapa enzim yang berperan dalam sintesis saponin seperti enzim kinase. Skualen sintasedan enzim $\mathrm{NADH}+$ kinase. Sedangkan DAG yang tidak larut dalam air berfungsi dalam membran plasma. DAG mengaktifkan enzim pada membran yaitu protein kinase $\mathrm{C}$ (PKC). Enzim ini menggunakan ATP untuk memfosforilasi beberapa enzim tertentu yang mengatur pada tahap-tahap metabolisme.

Berdasarkan penelitian kadar steviosida kalus stevia (Stevia rebaudiana Bert.) dilakukan dengan menggunakan metode HPLC (High Performance Liquid Chromatography) maka dapat disimpulkan bahwa pemberian konsentrasi ZPT 2,4-D yang lebih rendah tanpa adanya kombinasi dengan PEG 6000 menunjukkan hasil metabolit sekunder steviosida yang rendah, tetapi seiring dengan pemberian peningkatan konsentrasi ZPT 2,4-D yang dikombinasikan dengan PEG 6000 dapat meningkatkan kandungan metabolit sekunder steviosida dari induksi kalus stevia (Stevia rebaudiana).

Perlu diingat juga, pemberian konsentrasi PEG 6000 yang terlalu tinggi pada kalus menyebabkan kalus sulit menyerap air mengakibatkan stres osmosis yang berlebihan dan tanaman bisa mati. Kemampuan kalus dapat bertahan hidup pada media selektif PEG tergantung dari konsentrasi PEG, jenis tanaman dan lamanya kalus mengalami tekanan seleksi dalam media yang diberi cekaman osmosis. 


\section{KESIMPULAN}

Produksi metabolit sekunder steviosida yang tinggi diperoleh dari perlakuan $3 \mathrm{mg} / \mathrm{L}$ 2,4-D dan $15 \mathrm{mg} / \mathrm{L}$ PEG 6000) yaitu sebesar $4,846 \mathrm{mg} / \mathrm{g}$. Tetapi yang lebih efisien diperoleh pada perlakuan $1 \mathrm{mg} / \mathrm{L}$ 2,4-D dan $25 \mathrm{mg} / \mathrm{L}$ PEG 6000 yaitu sebesar $4,792 \mathrm{mg} / \mathrm{g}$. Pengamatan morfologi kalus (tekstur dan warna kalus) menunjukkan bahwa kalus bertekstur kompak dan berwana coklat akibat cekaman osmosis PEG 6000 memiliki kandungan metabolit sekunder steviosida tinggi.

\section{DAFTAR PUSTAKA}

Ariningsih, Ika, Sholichatun, \& Anggarwulan E. 2003. Pertumbuhan Kalus dan Produksi Antrakuonin Mengkudu (Morinda citrofolia) pada Media Murashige-Skoog (MS) dengan Penambahan Ion Ca 2+ dan $\mathrm{Cu} 2+$. Jurnal Biofarmasi 1(2): 39-43.

Chatsudthipong, V., \& Chatchai M. 2009. Stevioside and Related Compounds: Therapeutic Benefits Beyond Sweetness. Pharmacology \& Therapeutics. 121 (2009) 41-54.

Ernawati, A. 1992. Produksi Senyawa-Senyawa Metabolit Sekunder dengan Kultur Jaringan Tanaman I. Wattimena G A. Gunawan L W. Matjik N A. Syamsudin E, Wiendi NMA, Ernawati A, Editor. Bioteknologi Tanaman I. Bogor: PAU Bioteknologi IPB. Hlm, 160-220.

Fakhri, A. 2010. Kultur In Vitro Tanaman Theobroma cacao dengan Variasi Polietilen Glikol (PEG) 6000 dan Potensinya Untuk Produksi Metabolit Sekunder Katekin. Skripsi. Jurusan Kimia. Fakultas Matematika dan Ilmu Pengetahuan Alam. Universitas Andalas. Padang.

Fatima, A \& Shaista J.K. 2010. Some factors affecting the in vitro growth of Stevia rebaudiana Bertoni. Iranian Journal of Plant Physiology 1 (2), 61-68.

Geuns, Jan M.C. 2003. Molecules of Interest Stevioside. Phytochemistry 64: 913921.

Habibah, N. A. 2009. Efektivitas Penambahan Elisitor Asam Jasmonik dalam Peningkatan Sintesis Senyawa Bioaktif Andrografolid pada Kultur Suspensi Sel Sambiloto. Biosaintifika 1(1): 11-18.

Hartanti, M. F.; Nurhidayanti. T.; Muryono M. Budidaya Tanaman Tembakau (Nicotiana tabacum. L. var. Prancak 95) pada Cekaman Kekeringan Polyethylene Glykol (PEG) Secara In Vitro. https://www.google.com/digilib.its.ac.id/ ITSUndergraduate-18903-Paper305304.pdf (diakses tgl 15 April 2013).

Hendaryono, D.P. Sriyanti \& Ari W. 1994. Teknik Kultur Jaringan Pengenalan dan Petunjuk Perbanyakan Tanaman Secara Vegetatif-Modern. Yogyakarta: Kanisius.

Janarthanam, B., M. Gopalakrishnan and T. Sekar. 2010. Secondary Metabolite Production in Callus Cultures of Stevia rebaudiana Bertoni. Banglades Journal of Scientific and Industrial Researc. 45(3): 243-248.

Jitendra, M et all. 2012. Micropropagation of an Anti diabetic Plant - Stevia rebaudiana Bertoni, (Natural Sweetener) in Hadoti Region of South-East Rajasthan, India. ISCA Journal of Biological Sciences. Vol. 1(3), 37-42.

Madan, S. 2010. Stevia rebaudiana (Bert.) Bertoni - A Review. Indian Journal of Natural Products and Resources. Vol. 1 (3), pp. 267-286.

Pandiangan, M, Nainggolan, N. 2006. Prningkatan Kandungan Katarantin pada Kultur Kalus Chatarantus roseus dengan Pemberian Naphtalene Acetic Acid. Jurnal Hayati. 13(3): 90-94.

Salisbury, F.B. dan C.W. Ross. 1995. Fisiologi Tumbuhan. Jilid 3. Penerjemah: Lukman, D.R. dan Sumaryono. Bandung: Penerbit ITB.

Shirwaikar, Annie, Vinit P, Jay B \& Saleemulla K. 2011. Identification and estimation of stevioside in the commercial samples of stevia leaf and powder by HPTLC and HPLC. Research Article. 2(9): 09767126.

Sulastri. 2010. Pengembangan Alfalfal Tropis Kekeringan Hasil Radiasi Sinar UV-C: Seleksi In Vitro, In Vivo, dan Uji Multilokasi. Laporan Akhir. Program Intensif Terapan.

Yulinda, E. 2010. Kultur In Vitro Tanaman Centella asiatica dengan Beberapa Konsentrasi Polietilen Glikol (PEG) 6000 dan Potensinya Untuk Produksi Metabolit Sekunder Triterpenoid. Skripsi Sarjana Kimia. Jurusan Kimia. Fakultas Matematika dan Ilmu Pengetahuan Alam. Universitas Andalas. Padang.

Zulhilmi, S \& Netty W.S. 2012. Pertumbuhan dan Uji Kualitatif Kandungan Metabolit 
Sekunder Kalus Gatang (Spilanthes acmella Murr.) dengan Penambahan PEG untuk Menginduksi Cekaman Kekeringan Pertumbuhan dan Uji Kualitatif Kandungan Metabolit Sekunder Kalus Gatang (Spilanthes acmella Murr.) dengan Penambahan PEG untuk Menginduksi Cekaman Kekeringan. Jurnal Biologi Universitas Andalas (J. Bio. UA.) 1(1): 1-8. 